This is a self-archived version of an original article. This version may differ from the original in pagination and typographic details.

Author(s): Nikula, Tarja; Moore, Pat

Title: Exploring translanguaging in CLIL

Year: 2019

Version: Accepted version (Final draft)

Copyright: (C) 2016 Informa UK Limited, trading as Taylor \& Francis Group

Rights: In Copyright

Rights url: http://rightsstatements.org/page//nC/1.0/?language=en

Please cite the original version:

Nikula, T., \& Moore, P. (2019). Exploring translanguaging in CLIL. International Journal of Bilingual Education and Bilingualism, 22(2), 237-249.

https://doi.org/10.1080/13670050.2016.1254151 


\title{
Exploring Translanguaging in CLIL
}

\author{
Tarja Nikula ${ }^{1}$ and Pat Moore ${ }^{2}$
}

1 Centre for Applied Language Studies, University of Jyväskylä, Finland

2 Dept. of Languages and Translation, Universidad Pablo de Olavide, Spain

\begin{abstract}
After reviewing the concepts of Content and Language Integrated Learning (CLIL) and Translanguaging, this article presents an exploratory study of translanguaging in CLIL contexts. Employing illustrative extracts from a collection of CLIL classroom recordings in Austria, Finland and Spain we argue that both pedagogic and interpersonal motivations can influence language choices. We suggest that the L1 should be appreciated as a potentially valuable tool in bilingual learning situations and that there is a need for increased awareness-raising around this question.
\end{abstract}

\section{Key words}

CLIL, translanguaging, classroom discourse, bilingual repetoires, orientations

\section{Introduction}

The purpose of this article is to participate in the academic discussion on the role of biand multilingualism in Content and Language Integrated Learning (CLIL), approached from the viewpoint of translanguaging, a concept that has rapidly gained ground in multilingualism research but that has only rarely been applied in CLIL research (although see Moore and Nikula 2016). Both translanguaging and CLIL can be understood as umbrella terms, the former relating to bilingual behaviour and the latter to bilingual education. In this article, after discussing each concept in the light of existing research, we will consider the usefulness of the notion of translanguaging for CLIL by exploring episodes of CLIL classroom discourse originating from three European contexts: Austria, Finland and Spain. We believe a more nuanced picture of 
translanguaging should contribute to the appreciation of its potential in bilingual education, not least in CLIL classrooms.

CLIL refers to an approach which merges subject and (foreign) language development in educational contexts. CLIL emerged in Europe in the nineties, instigated largely through top-down promotion by educational policy-making and through bottom-up localized initiatives (Dalton-Puffer 2008, 139). Over the last three decades it has spread across the continent to the extent that in some areas it is verging on the mainstream, albeit typically as an option rather than an obligation (for example see Bertaux [2008] on France; Breidbach and Viebrock [2013] on Germany; Leone [2015] on Italy), and is also moving beyond the continent (for example see Turner [2013] on Australia; Lo and Lin [2015] on Hong Kong).

Recently there has been a flurry of debate regarding the similarities and differences between CLIL and other forms of bilingual education, particularly immersion, (in chronological order, see Lasagabaster and Sierra 2010; Somers and Surmont 2012; Cenoz, Genesee, and Gorter 2014; Dalton-Puffer et al. 2014; Nikula and Mård-Miettinen 2014; Cenoz 2015a). At the outset CLIL was greatly influenced by immersion principles, to the chagrin of some English Language Teaching (ELT) specialists (see Hall and Cook 2012, 298), but as it has evolved it has developed its own characteristics.

According to Dalton-Puffer and Smit (2013, 546), one of the core defining features of CLIL lies in seeing it as content, rather than language, driven. CLIL classes are timetabled as content classes and taught by content teachers who are generally not native-speakers of the target language (TL). The TL is usually a foreign language (FL) and English is the dominant TL in European CLIL which can be seen both as a strength and a weakness: While knowing English presumably prepares learners for participation in the global community - and this is usually among the main motivations for introducing CLIL - the prevalence of English may be problematic if it diminishes the importance of other languages.

The core of CLIL lies in integration but rather than simply a matter of combining content and language to support FL language development, integration is a multi-dimensional and highly complex phenomenon (see Nikula et al. 2016). One of the issues that has rarely been addressed is integration as a matter of merging language resources involved (but see Moore and Nikula 2016), which is surprising given the overall task of CLIL to support the development of future bilinguals. As Nikula and 
Mård-Miettinen (2014) have pointed out, there is a need for CLIL to be more informed by both bi- and multilingual practice and multilingualism research. The purpose of this paper is to argue that translanguaging represents a cutting edge take on this practice.

The roots of the term translanguaging lie in Welsh soil. The term trawsieithu was coined in the 1980s by Williams to describe a pedagogic strategy involving the deliberate alternation of languages for input and output in bilingual (English/Welsh) classrooms (Lewis, Jones, and Baker 2012a). The strategy was designed to foster 'duallanguage processing' (644) as a tool for bilingual content education by both exploiting and thereby reinforcing the learners' bilingual linguistic competences. Baker (2000, 104-5) observes:

It is possible in a monolingual context, for students to answer questions or write an essay without fully understanding the subject. Whole sentences or paragraphs can be copied or adapted from a textbook without really understanding them. This is less easy in a bilingual situation. To read and discuss a topic in one language, and then to write about it in another, means that the subject matter has to be properly 'digested' and reconstructed.

Albeit initially conceived of as an educational strategy, translanguaging also reflects typical bilingual behaviour. In 2002, addressing the Welsh Assembly, Williams cited the example of a child taking a telephone message in one language and passing it on in another (alternation of input and output) and suggested that translanguaging is "a natural skill for any bilingual" (29).

As interest in translanguaging has grown, so has an understanding of its implications and, just as the idea of a bilingual being two monolinguals in one has been rejected (Grosjean 1989), so the idea that bilinguality implies dual/separate systems is crumbling. Garcia suggests "translanguaging posits that bilinguals have one linguistic repertoire from which they select features strategically to communicate effectively" (2012, 1; original italics). Blackledge and Creese declare "The idea of 'a language' may be important as a social construct, but it is not suited as an analytical lens through which to view language practices" $(2014,1)$.

Concurrently, other models of communicative malleability have emerged (e.g. Blommaert's super-vernaculars [2012]; Otsuji and Pennycook's metrolingualism [2010]; Jørgensen et. als’ polylanguaging [2011]). They may have distinct traits yet share a desire to reconceptualise multilingual practices by treating 'language' as a 
flexible resource without hard and fast demarcations between different language systems. For further discussion see Blommaert and Rampton (2011) or García and Li (2014, 36-42).

This reconceptualisation represents a radical step and is not uncontroversial. Orman (2013) rejects these models, particularly polylanguaging, as "telementational" bemoaning the fact that although they reject the ontological suppositions of discrete languages and codes, they nevertheless often use code-based analysis when dissecting discourse. This criticism strikes a chord. It is difficult to analyse instances of speakers moulding verbal repertoires without resorting to codification (L1, L2 etc) as a means of describing the process. García and $\operatorname{Li}(2014,52)$ acknowledge, "the language we use continues to reflect the social categories of autonomous languages". We are thus grappling with cognitive dissonance.

In a similar vein, in reviewing recent research we have noted a tendency to treat translanguaging as if it were simply a re-branding of code-switching (for example see Adamson and Fujimoto-Adamson [2012, 59]; Gallagher and Colohan [2014, 10]; Gené Gil, Garau, and Salazar Noguera [2012, 133ff]; Turner [2013, 398]; Schwartz and Asli $[2014,26])$. However, we feel it is important to stress that translanguaging goes beyond code-switching/mixing. It does encompass the idea of alternation/merger in a way similar to code-switching but extends the notion (García 2009, 45) to encompass a variety of typical bilingual communicative strategies including translation (Hélot 2014) and a range of derivational morphological processes including calques, coinages and borrowings (Makalela 2013).

Furthermore, there is an epistemological difference: even though Conversation Analysis-based code-switching studies (e.g. Auer 1998; Cromdal 2004) have emphasised its social-interactional aspects, the roots of the term lie in linguistics and, as the name implies, tend to be aligned with views that emphasise the idea of languages as separate linguistic systems. However, as discussed above, translanguaging orientates to discursive practices (García and Li 2014, 22) and is more sociolinguistically and ideologically inclined (Lewis, Jones and Baker 2012b, 667-8). The notion of orientation is important here: language can be approached both as a system and as discursive resource, just as light in physics can be justifiably conceived of both as waves and particles. In this paper our exploration of translanguaging places the discursive resource orientation in focus. 
The potentially competing terms mentioned above (polylanguaging etc.) are largely associated with research on performative aspects of language in society-at-large whereas our interest lies in educational praxis, and translanguaging is the concept which has been most closely aligned with education. Indeed, the emergence of translanguaging in the field can be associated with a paradigm shift (Cenoz 2015b) in language education. That said, most discussions of educationally-situated translanguaging to date have drawn on evidence coming from what we might term 'naturally' multilingual environments - frequently superdiverse (e.g. Garcia in New York, 2009); post-colonial (e.g. Makalela in South Africa, 2013) or regional (e.g. Hélot in Alsace, 2014) and/or focusing on 'minoritised' heteroglossic groups (e.g. Creese and Blackledge on complementary schools in the UK, 2010). These contexts do not coincide with a typical CLIL scenario (as outlined above) yet CLIL is bilingual education and this implies a propensity for multilingual practices. Indeed, from the perspective of emerging bilingualism, CLIL - tasked with creating bilinguals, offers an interesting opportunity to observe just how the process is enacted.

\section{Translanguaging in CLIL}

The term translanguaging is actually no stranger to CLIL. An early CLIL initiative, TIE-CLIL, $($ TIE = Translanguage in Europe), ran from 1998-2002 and was mainly interested in teacher development. In publications related to the project (e.g. Marsh and Langé 1999) there is, strangely, no elucidation of the term 'Translanguage', yet there are clear indications of a role for the first language (L1):

CLIL should not be thought of as necessarily requiring $100 \%$ use of a foreign language in the learning process. CLIL invites the use of both the mother tongue and an additional language in the learning context. (162).

In one of the first major European reports on CLIL: CLIL/EMILE The European Dimension, Trans-languaging (having gained a hyphen) was glossed as 'the use of more than one language':

[A] teacher may speak in one language, and a pupil reply in another.

Alternatively, students may work as a pair speaking through one language, whilst analysing materials produced in another. $(2002,17)$.

The report includes seventeen case studies of European CLIL with summary descriptions of key case characteristics under diverse headings (time-frame; target age 
range; interdisciplinarity etc.), including Trans-languaging. Reviewing the studies, these demonstrate a broad range of potential for translanguaging practices. In a French scenario, for example, we find "Trans-languaging is allowed when it can avoid a breakdown in communication, but does not normally need to be used more often because of the additional language training provided in the language classes, and the support provided by language teachers." (98). This is reminiscent of the L1 as recourse view typical of early Second Language Acquisition (SLA) research. In a Finnish context we find "At lower levels the teacher uses the target language mostly, and the pupils reply in the mother tongue: But as they progress to higher levels, pupils increasingly use the target language." (106). This suggests translanguaging as scaffold and monolingual target language (TL) use as the goal. In a Bulgarian scenario "Trans-languaging is viewed as a positive and constructive part of the educational experience, and not a weakness, unless it involves simple interpretation." (148). This seems to imply a more repertoire-based approach to language choices although the comment on interpretation suggests it might be restricted to language for learning and not necessarily for mundane communication.

References to translanguaging in 'handbook' approaches to CLIL continue to reflect a rather superficial treatment of the issue, perhaps due to the nature of the genre. Marsh et al. (2011, 21) mention translanguaging when they state that CLIL teacher strategies should include the ability to:

[S] upport continuous language growth through a repertoire of didactic strategies (e.g., Zone of Proximal Development, error awareness and correction, first language transfer and interference, translanguaging, anti-plateauing strategies and modelling).

Unfortunately, however, they do not clarify what they understand by these terms nor describe exactly how they envisage them working. Coyle, Hood, and Marsh (2010) advocate "blended instruction" in CLIL through code-switching (15) which they associate with translanguaging, defined as "a systematic shift from one language to another" (16). While the original Welsh model of translanguaging, alternating input and output languages, could be envisaged as systematic (see Williams 2002, 4); we would suggest that a more modern take on translanguaging practices would consider them "spontaneous, impromptu and momentary" (Li 2011, 1224) and thus not systematic at all. 
Although she does not mention translanguaging per se, Lin argues that "CLIL does hold good potential to distinguish itself from traditional L2 immersion models by becoming more flexible and balanced about the potential role of L1 in CLIL lessons" (2015, 75). Regarding empirical research around L1 in CLIL, Gierlinger (2015) provides an interesting study focusing on teacher behaviour: He employs classroom recordings to inform reflective teacher interviews and identifies a set of scenarios where the L1 may fruitfully come into play, motivated by behavioural, classroom and task management, and knowledge scaffolding considerations as well as affective factors. A couple of other studies have explored CLIL teachers' self-reported attitudes to L1 use (Lasagabaster 2013; Méndez García and Pavón 2012). These have generally agreed that there is a place for the L1 in CLIL classrooms, and that it can be useful for disambiguation and cross-linguistic comparison or for classroom management and disciplinary matters. However, researchers are concerned that teacher L1 use is ‘intuitive' (Méndez-García and Pavón) and 'random' (Lasagabaster) and are unanimous in calling for further research.

Two classroom-based studies compare L1 use by teachers and learners in CLIL and EFL classrooms (Gené Gil, Garau, and Salazar Noguera 2012; Kontio and Sylvén 2015). Both studies focus on the question of impetus, Gené Gil, Garau and Salazar Noguera distinguishing between pedagogic and more generally communicative functions (eg. classroom management) and Kontio and Sylvén comparing learnerinitiated and teacher-impelled alternation. These studies reveal interesting parallels: both find, for example, that adherence to the TL, and TL norms, are more rigidly enforced in the FL classes and that TL use in CLIL scenarios is more flexible and more 'playful' (Kontio and Sylvén).

That said, the above studies operate within code-switching/alternation paradigms; translanguaging may be mentioned in passing but in ways that serve to reinforce our argument that many CLIL researchers may not be fully aware of the ramifications of the concept. To illustrate, Gierlinger acknowledges translanguaging but frames his discussion of results around code-switching; Gené Gil, Garau and Salazar Noguera subsume it into codeswitching and Lasagabaster limits it to the original Welsh model when he claims "translanguaging would take place if students read about a topic in the L1 and present their work in the L2" $(2013,2)$.

This is not to say that William's pedagogic strategy model is without merit. Lin $(2015,80)$, for example, regrets the fact that so little research has been done around 
systematic alternation in CLIL contexts. In Italy, Agolli (2015) describes a pre-CLIL initiative known as CLSL - Content and Languages Shared Learning - whereby EFL teachers are tasked with reinforcing and expanding on content introduced in the L1 but this is at primary level and although the syllabus is bilingual, the classrooms are still envisaged as monolingual. One of the few studies addressing planned translanguaging in secondary education (albeit not disambiguating between translanguaging and codeswitching) is Gallagher and Colohan (2014). Their data-gathering involved a 'twisted' dictation activity with both content and language related goals (reviewing the topic of climate and highlighting adverbial placement). The control group wrote the sentences in English and the experimental group translated them into Italian. Gallagher and Colohan argue that this technique enhances awareness-raising around grammatical differences between the L1 and TL. They also note that the students from the experimental group reacted very favourably to the exercise, associating it with "the reallife skill of interpreting" (10), giving them an opportunity to display bilingual skills.

At this point it should be noted that the expansion of the notion of translanguaging - from contextualised pedagogical to generalised discourse strategy gives rise to a potential for tensions regarding different roles and functions of translanguaging in CLIL classroom discourse. Classroom discourse is multi-layered and from the perspective of speaker goals/intentions several things will often be transpiring simultaneously. Perhaps the classic distinction here is between regulative and instructional language (eg. Christie 2000); yet more recently the question of interpersonal language has been receiving increasing attention (eg. Erhman and Dörnyei 1998). Interestingly, research in FL classrooms has often flagged regulative, classroommanagement language as featuring L1 (Littlewood and Yu 2011) and, as seen above, CLIL research has echoed this. Yet if we are to engage with translanguaging in education as a tool to foster learning it needs to be factored into instructional language and if we envisage CLIL classrooms as spaces for emerging bilingual behaviour we need to address the question of language choice beyond pedagogically-motivated functions.

Lewis, Jones and Baker (2012a, 650) propose a distinction which initially appears useful here. They differentiate between 'Classroom' and 'Universal' modes of Translanguaging. Classroom Translanguaging, as the name suggests, refers to classroom practice. Lewis, Jones and Baker note that this may imply "planned" or "serendipitous" translanguaging but always "with a pedagogic emphasis". The idea of 
planned translanguaging conflates with the original Welsh model but we would suggest it might more usefully be regarded as a cline, ranging from pre-planned translanguaging activities such as Gallagher and Colohan's twisted dictation (above) to a pre-disposition to translanguaging when it might further learning goals.

In contrast, Universal Translanguaging relates to typical bilingual behaviour: "irrespective of context and particularly for gaining understandings, everyday communication, and achievement in interactions irrespective of site." (650). Lewis, Jones and Baker further note: "While Universal Translanguaging includes the classroom as one context among many, retaining 'Classroom Translanguaging' enables a discussion about learning and teaching style and curriculum planning." What this means is that both Classroom and Universal Translanguaging may occur in the classroom. The former, prompted by teaching/learning intent, we could gloss as learning bilingually and the latter, with a more broadly defined communicative intent, as 'simply' behaving like a bilingual.

The potential problem here is that if Universal translanguaging includes Classroom translanguaging and Classroom translanguaging can feature Universal translanguaging, the application of the model to explore bilingual behaviour could become difficult. We have argued elsewhere that for classroom contexts, a useful way to delineate between different uses of translanguaging is to draw attention to whether it is 'orienting to language in content' or 'orienting to the flow of interaction' (Moore and Nikula 2016). The former refers to translanguaging with explicit language focus - often clarifying lexis/terminology important for the content area in question - to scaffold meaning negotiation and the teaching and learning of content. The latter refers to instances of translanguaging which, rather than making language salient, are unmarked, geared towards the flow of interaction, for example as signals of interactional alignment.

\section{Illustrating Translanguaging Practices in CLIL}

In this section, we illustrate translanguaging as bilingual behaviour in CLIL classrooms by analysing the use of multilingual resources in a selection of extracts deriving from a pool of CLIL classroom recordings from different European countries - Austria, Finland and Spain - compiled during the research project Conceptualising Integration in CLIL - ConCLIL (2011-14) which involved researchers from Austria, Canada, 
England, Finland and Spain and was funded by the Academy of Finland. Our goal was to explore the notion of integration - the project keystone - from the perspective of language choice/use (see Moore and Nikula 2016). This was conceived of as an exploratory study, utilising qualitative discourse analysis to identify instances of bilingual talk in CLIL classrooms. (For information regarding the original datagathering procedures etc. see Dalton-Puffer 2007 [Austria]; Llinares and Whittaker 2007 [Spain] and Nikula 2005 [Finland].)

When doing this we made no distinction between teacher and learner language use because, in line with the typical CLIL scenario outlined above, none of the teachers involved are native-speakers of the TL (English) so from a translanguaging perspective their behaviour is just as interesting as their students'. Overall English clearly dominates in most of the classroom recordings we have been working with but they do all include translanguaging episodes to greater or lesser degrees. However, rather than focusing on quantifying L1/L2 use, we are interested in illustrating translanguaging as a locally situated discursive practice and in using the data across a range of geographical contexts to explore and exemplify translanguaging behaviour. Nor do we seek to compare between proficiency levels. This would require different data, (longitudinally gathered) and different techniques.

As pointed out above, in a previous publication (Moore and Nikula 2016) we employed short (3-5 line) extracts featuring translanguaging, while focusing on a distinction between orientating to language in content (i.e. learning bilingually) and orienting to the flow of interaction (i.e. behaving bilingually). However, we also have to recognise that clear-cut distinctions tend towards generalisation and can thus be problematic, and so in this paper we seek to complement the picture by examining longer stretches of discourse to illustrate bilingual behaviour in CLIL classroom discourse to gain a more comprehensive view of translanguaging as situated practice. Here we focus on three extracts, each one featuring a different location and a different content subject: Biology in Finland, History in Austria and Technology in Spain. These three extracts were chosen because, both separately and in conjunction, we feel they illustrate the highly contingent nature of translanguaging as discursive practice in CLIL classroom interaction.

Extract 1: Biology. Finland. 
This class of 14-15 year old students is discussing pregnancy and childbirth. This teacher habitually provides L1 equivalents for key terms, thereby apparently demonstrating a pre-disposition to translanguaging to support learning as mooted above. Sometimes it seems that the L1 provision is 'simply' translation to strengthen bilingual learning, for example in one lesson the term tonsils comes up and it is clear learners already know what tonsils are (in Finnish). In the extract below the topic turns to caesarean (c-) sections and, after a meaning negotiation in lines 2-12 where the teacher also signals uncertainty regarding the term in English, he provides the term in Finnish (line 19).

$1 \mathrm{~T} \quad$ yeah in many cases of twin pregnancies they do th- this

2 S1 what's it called

3 T um

$4 \quad$ S2 cir- c section or something.

$5 \mathrm{~T}$ section [or ]

6 S3 [circum]cision [circumcision]=

$7 \mathrm{~S} 1$ [c section ]=

$8 \quad$ S4 $=$ what?

9 S3 circum- no that's no

10 S4 dude [ : ]

11 S3 [ : ] that's not the word

12 S4 cir- c section

$13 \mathrm{~T}$ c section how do you spell it

14 S5 [it's a semi (xx) ]

15 S2 [I don't know but I] [just heard] it [been said]

$16 \mathrm{~S} 1 \quad$ [ huh? ] [ (xxx) ]

$17 \mathrm{~T}$ uhuh okay yeah (1.6)

18 S5 c section (2.3) c section

$19 \mathrm{~T}$ yeah in finnish keisarinleikkaus /caesarean section/ (1.2) um

$20 \quad$ S4 $\quad(x[\mathrm{x})]$

$21 \quad \mathrm{~S} 2 \quad[(\mathrm{x})]$

22 S6 why is it [keisarinleikkaus]

$23 \mathrm{~S} 1 \quad$ [ I know this ] [ ( $\mathrm{xxx})$ ] 
25 S7 nyt leikataan/now let's cut/

26 S? $\quad{ }^{\circ}$ keisarinleikkaus ${ }^{\circ}$

$27 \quad \mathrm{~S} 2 \quad$ or $(\mathrm{x})$ emperor's ( $\mathrm{xx}[\mathrm{x}$ English) $]$

$28 \quad$ S6

In doing so, he clarifies the c- in c-section and thereby prompts a rapid multilingual exchange around the etymology of the term between the learners (lines 2227). Martin-Beltrán $(2014,12)$ suggests that a useful translanguaging technique is to encourage the learners to "play language detectives", to look for and discuss similarities and differences (cognates and false cognates) across languages. In this extract the learners seem to need no encouragement. Exploiting bilinguality for pedagogic purposes can help to strengthen the cognitive processing of notions (Lin 2015, 84); and in this case it seems logical to assume that the fact that the terms are etymologically related could reinforce acquisition. Thus by being predisposed to translanguaging the teacher may well be creating opportunities for learning which would not be present if the discourse was TL monolingual.

Most of the translanguaging in this first extract is clearly orienting to learning but in line $25 \mathrm{~S} 7$ translanguages in an attempt to move the discussion along. She creatively plays on the word leikataan (cut), in a 'doctor's voice', as if to announce the beginning of an operation. Through such performative enactment she introduces a humorous aspect to communication (also evident when discussing the English term in lines 6-11) and, rather than focusing on learning, is exploiting her language repertoire for communicative effect.

\section{Extract 2: History. Austria}

At the beginning of this next extract, there is a short exchange between S2 and S3 in German. This is unrelated to the learning matter at hand and it could be argued that the learners' language choice emphasises the off-record nature of the exchange and serves to exemplify the multi-layered nature of much classroom discourse as learners socially align to different priorities concurrently as learners and classmates.

Like the Finnish biology teacher above, the Austrian history teacher in this classroom seems to employ translanguaging to oil the process of learning: when explaining she often provides simultaneous bilingual glosses of difficult or important 
concepts. In the following extract one of the students (S1), a 14 year old girl, is giving a short presentation. As she progresses she is concurrently summarising key points in German. It is clear that by emulating her teacher and employing translanguaging in this way, to orient to the learning of the matter at hand, she is not 'falling back' on her L1 here, rather it could be argued that, as her teacher does, she is skilfully ensuring that everyone has the opportunity to follow what she is saying.

1 S1 the female workers make a revolt

2 S2 ich muss aufs klo gehn /I need to go to the loo/

3 S3 dann geh / then go/

$4 \quad$ S1 and

$5 \quad \mathrm{~S} 2 \quad(\mathrm{xxx})$

6 Ss $;$; $;$

$7 \mathrm{~S} 1 \mathrm{hmm}$ the revolt (.) and in this revolt also (.) they- a sl- the slogan of the

8 revolt was was peace land and bread (.) and they want that the that the tsar

9 (.) ab- (.) abdicate also dass der zar abdankt / that the tsar abdicate/ and so

10 the the tsar did also der zar hat dann abgedankt /and so the tsar abdicated/

$11 \quad$ S3 $\quad(\mathrm{xxx})$

12 S1 yeah, and a new duma were found- ah were founded (.) and in this duma

13 revolutionary and bourgeois parties a-ah they the also this duma consist of

14 revoluna- (-) (.) revolutionary and bourgeois parti- bourgeois das sind die

15 bürgerlichen gewesen, also die schon etwas reicheren leute/they were

16 the bourgeoisie, and the richer people/

$17 \mathrm{~T}$ bourgeois [[corrects pronunciation]]

$18 \mathrm{~S} 1$ bourgeois genau /right/ ja und das war's dann, weil /yeah that's right,

19 while/ the riot (.) of- asso . ja und dann hat der zar abgedankt (.) gut /yes

20 and then the tsar abdicated, good/ and ah also workers' and soldiers' councils

21 were elected (.) and ah o- ich seh nix /I dunno/ - and when the tsar abdicate

22 the workers (.) the workers (.) the workers and the peasants expelled the

23 owners from the land

It is also worth highlighting the way that S1 punctuates her discourse with a variety of L1 discourse markers also, genau, gut. As previous research has demonstrated, mundane bilingual speech frequently includes discourse markers from the full repertoire 
(Hlavac 2006; Torres 2002). So, while she is translanguaging to underpin content learning she is also translanguaging to structure her discourse and in doing so simultaneously orienting to pedagogic and interpersonal concerns.

Extract 3: Technology. Spain.

In this final extract, 11-12 year old learners are working in groups, completing a handson task while the teacher circulates. We know that FL learners often use their L1 when put in groups (e.g. Hancock 1997; Storch and Wigglesworth 2003) and we should not necessarily expect CLIL learners to be any different; so it comes as little surprise to find the learners speaking Spanish. As Brooks and Donato (1994) argue, this might make teachers nervous, even reluctant to plan for group work, but we would suggest that a fruitful way to proceed might be to proactively plan for language use which will involve the learners' entire repertoire (viz. the original Welsh model of translanguaging) (and see Lin 2015).

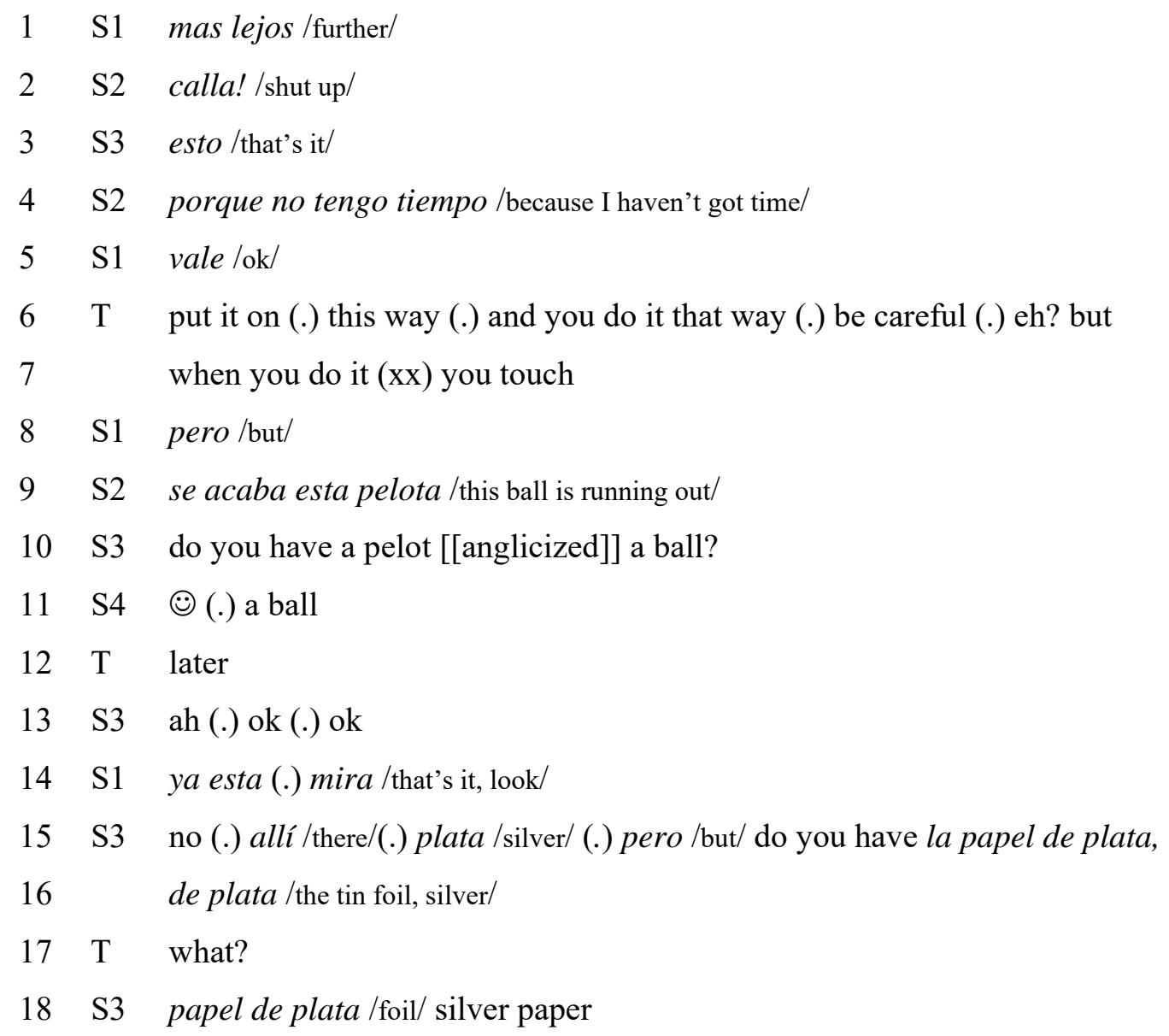


$19 \mathrm{~T}$ I don't know (.) eh (.) foil (.) eh (.) silver paper (.) it's foil (.) eh I don't know

Although at another point in the lesson he does translanguage: employing Spanish when giving instructions for the use of a potentially dangerous tool, in this extract the teacher sticks to English. Yet it is clear that the learners can understand him and that communication is happening (of course the exchanges are also highly deictic). It is still fundamentally bilingual discourse.

In multilingual spaces language choices can be taken as indicators of alignment (Cromdal 2004; Ustunel and Seedhouse 2005) and from this perspective S3, presumably prompted by the teacher joining their group, appears to make an effort to align with medium of instruction norms. In doing so he also employs typical translanguaging techniques: In line 10, he first anglicises the Spanish pelota to pelot (a tactic which S4 acknowledges) and then, in line 15, provides a calque for papel de plata 'silver paper'. A language-as-system perspective might consider these errors, interference through code-switching perhaps; but if we treat them as translanguaging we can applaud both the speaker's willingness to participate and his creativity in doing so.

\section{Conclusions}

The purpose of this paper has been twofold. Firstly, we have discussed the notion of 'translanguaging' by reference to research literature. Secondly, we have explored the usefulness of the notion of translanguaging for CLIL contexts, arguing that both research and practice would benefit from approaches that acknowledge the meaningfulness of bi- and multilingual practices. Our illustrative extracts suggest, and as we have also shown elsewhere (Moore and Nikula 2016), bilingual practices abound in CLIL classroom discourse and serve a variety of purposes ranging from orienting to learning of content and language to ensuring the flow of interaction or simply indicating that the learners treat the space as bilingual (Nikula 2007).

As CLIL research has shown (above), and as the extracts display, CLIL teachers seem to have a sense that the L1 may serve certain purposes. Research into CLIL teacher attitudes has listed functions/events/acts for which L1 use is condoned. There may also be an expectation for research to provide such lists as guidelines for teaching. However, we would caution against such a proposition as lists can easily result in overgeneralisation and a lack of context-sensitivity (see also Chimbutane 2014; Lin 2015; 
Macaro 2006). Instead, we see awareness raising as the key and sensitivity towards translanguaging as something that will come into play as and when necessary and/or appropriate in CLIL classrooms. In other words, it would be helpful for teachers to have an overall understanding of translanguaging, not only as a pedagogic strategy to support learning but also as a feature of natural bilingual discourse, which they and their students can employ according to the situational demands.

As noted above, this paper has presented an exploratory study with which we seek to make a contribution to the ongoing academic discussion concerning bilinguality and translanguaging in CLIL classrooms. More research is obviously needed to understand the phenomenon better. Lewis, Jones and Baker took the first steps in acknowledging that translanguaging in the classroom may be planned or serendipitous $(2012,650)$. Serendipidity by nature is unplanned but it might be useful to distinguish between degrees of planning: as a starting point perhaps between a strong planned classroom mode à la original Welsh model and a weak planned mode, a pre-disposition to translanguaging as evidenced for example in the unsolicited provision of L1 equivalent terminologies in the Finnish and Austrian extracts above. The strong mode implies conscious decision on the part of teachers, but how conscious are they of the weak mode? In other words, if asked to reflect upon it, would they describe the L1 as resource or recourse? Taking an informed translanguaging stance would imply the former. It is here worth commenting on the fact that none of the classroom recordings we have been working with include examples of deliberate pre-planned input/output variation and it would be interesting to investigate how common this practice actually is. Another fruitful avenue for future research would be to adopt a longitudinal approach to how translanguaging evolves during the CLIL experience. On this question, as we argue elsewhere (Moore and Nikula 2016), we would not expect translanguaging to diminish with proficiency, since this runs counter to conceiving of it as normal bilingual behaviour, but rather coming to an understanding of whether the purposes for and ways in which translanguaging is used change as bilingual skills develop. Thirdly, given the call for awareness raising above, it would also be useful to investigate the effects of teachers' growing awareness of translanguaging as a bilingual strategy both on their perceptions of CLIL and on actual classroom practices. 
Notes

1. Transcription: Since the recordings were originally transcribed by different researchers and with varying levels of detail, we first had to homogenise the transcriptions. The following set of conventions covers interactional phenomena that were addressed in all data sets:

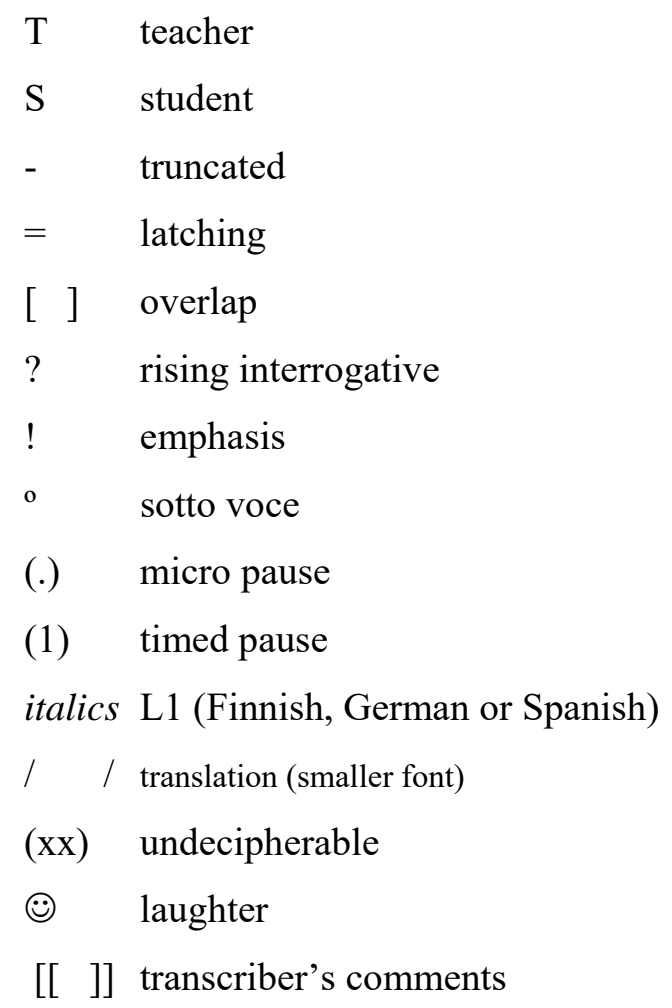

References

Adamson, J., and N. Fujimoto-Adamson. 2012. "Translanguaging in Self-Access Language Advising: Informing Language Policy". Studies in Self-Access Learning Journal 3 (1): 59-73.

Agolli, R. 2015. "Content and language symbiosis in a maieutic, translanguaging pattern (CLSL): An exploratory practice in Italy." Latin American Journal of Content and Language Integrated Learning 8 (1): 43-54.

Auer, P. ed. 1998. Code-Switching in Interaction. London: Routledge.

Baker, C. 2000. The Care and Education of Young Bilinguals. Clevedon: Multilingual Matters. 
Bertaux, P. 2008. “An Example of Mainstream CLIL in France: Sections Européennes et de Langue Orientale". In CLIL e l'Apprendimento delle Lingue. Le Sfide del Nuovo Ambiente di Apprendimento, edited by C.M. Coonan, 233-238. Venice, Italy: Libreria Editrice Cafoscarina.

Blackledge, A., and A. Creese, eds. 2014. Heteroglossia as Practice and Pedagogy. Heidelberg: Springer.

Blommaert, J. 2012. "Supervernaculars and their dialects." Dutch Journal of Applied Linguistics 1 (1): 1-14.

Blommaert, J., and B. Rampton. 2011. "Language and Super Diversity". Diversities 13 (2): $1-22$.

Breidbach, S., and B. Viebrock, eds. 2013. Content and Language Integrated Learning (CLIL) in Europe: Research Perspectives on Policy and Practice. Frankfurt am Main: Peter Lang.

Brooks, F. B., and R. Donato. 1994. "Vygotskyan approaches to understanding foreign language learner discourse during communicative tasks". Hispania, 77: 262-274.

Cenoz, J. 2015a. "Content-based Instruction and Content and Language Integrated Learning: the same or different?" Language, Culture and Curriculum 28 (1): 8-24.

Cenoz, J. 2015b. "Discussion: Some Reflections on Content-Based Education in Hong Kong as Part of the Paradigm Shift”. International Journal of Bilingual Education and Bilingualism 18 (3): 345-351.

Cenoz, J., F. Genesee and D. Gorter. 2014. "Critical Analysis of CLIL: Taking Stock and Looking Forward”. Applied Linguistics 35 (5): 242-262.

Chimbutane, F. 2014. "Codeswitching in L1 and L2 Learning Contexts: Insights from a Study of Teacher Beliefs and Practices in Mozambican Bilingual Education Programmes". Language and Education 27 (4): 314-328.

Christie, F. 2000. "The language of classroom interaction and learning”. In Researching Language in Schools and Communities. Functional Linguistics Perspectives, edited by L. Unsworth, 184-205. London \& Washington: Cassell.

Coyle, D., P. Hood and D. Marsh. 2010. CLIL: Content and Language Integrated Learning. Cambridge: Cambridge University Press.

Creese, A., and A. Blackledge. 2010. "Translanguaging in the Bilingual Classroom: a Pedagogy for Learning and Teaching?” The Modern Language Journal 94 (1): 103 115 . 
Cromdal, J. 2004. "Building Bilingual Oppositions: Code-switching in Children's Disputes”. Language in Society 33 (1): 33-58.

Dalton-Puffer, C. 2007. Discourse in Content and Language Integrated Classrooms. Amsterdam: John Benjamin.

Dalton-Puffer. C. 2008. "Outcomes and Processes in CLIL: Current Research from Europe”. In Future Perspectives for English Language Teaching, edited by W. Delanoy and L. Volkmann, 139-157. Heidelberg: Carl Winter.

Dalton-Puffer, C. and U. Smit. 2013. "Content and Language Integrated Learning: A Research Agenda". Language Teaching 46: 545-559.

Dalton-Puffer, C., A. Llinares, F. Lorenzo and T. Nikula. 2014. "“'You Can Stand Under My Umbrella": Immersion, CLIL and Bilingual Education. A Response to Cenoz, Genesee and Gorter (2013)”. Applied Linguistics 35 (2): 213-21.

Ehrman, M. E., and Z. Dörnyei. 1998. Interpersonal dynamics in second language education: The visible and invisible classroom. California: Sage Publications, Inc.

Gallagher, F., and G. Colohan. 2014. "T(w)o and Fro: Using the L1 as a Language Teaching Tool in the CLIL classroom”. Language Learning Journal (Advanced Access). Doi: 10.1080/09571736.2014.947382.

García, O. 2012. "Theorizing Translanguaging for Educators”. In Translanguaging: A CUNY-NYSIEB Guide for Educators, edited by C. Celic and K. Seltzer, 1-6. New York: CUNY-NYSIEB.

García, O. 2009. Bilingual Education in the 21st Century: A Global Perspective. Oxford, UK: Wiley-Blackwell.

García, O. and W. Li. 2014. Translanguaging: Language, Bilingualism and Education. Basingstoke: Palgrave Macmillan.

Gené Gil, M.G., M.J. Garau and J. Salazar Noguera. 2012. “A Case Study Exploring the Language Choice between the Target language and the L1s in Mainstream CLIL and EFL Secondary Education”. Revista de Lingüística y Lenguas Aplicadas 7: 133-145.

Gierlinger, E. 2015. “'You Can Speak German, Sir”: on the Complexity of Teachers' L1 Use in CLIL". Language and Education (Advance Access). doi: $10.1080 / 09500782.2015 .1023733$

Grosjean, F. 1989. "Neurolinguists, beware! The bilingual is not two monolinguals in one person". Brain and Language 36: 3-15.

Hall, G., and G. Cook. 2012. "Own-language Use in Language Teaching and Learning: State of the Art". Language Teaching 45 (3): 271-308. 
Hancock, M. 1997. "Behind Classroom Code Switching: Layering and Language Choice in L2 Learner Interaction". TESOL Quarterly 31 (2): 217-235.

Hélot, C. 2014. "Rethinking Bilingual Pedagogy in Alsace: Translingual Writers and Translanguaging". In Heteroglossia as Practice and Pedagogy, edited by A. Blackledge and A. Creese, 217-237. Heidelberg: Springer.

Hlavac, J. 2006. "Bilingual Discourse Markers: Evidence from Croatian-English Codeswitching”. Journal of Pragmatics 38 (11): 1870-1900.

Jørgensen, J.N., M.S. Karrebæk, L.M. Madsen and J.S. Møller. 2011. "Polylanguaging in Superdiversity". Diversities 13 (2): 23-38.

Kontio, J., and L.K. Sylvén, 2015. "Language Alternation and Language Norm in Vocational Content and Language Integrated Learning (CLIL)”. Language Learning Journal 43 (3): 271-285.

Lasagabaster, D. 2013. "The use of the L1 in CLIL Classes: the Teachers' Perspective". Latin American Journal of Content and Language Integrated Learning 6 (2): 1-21.

Lasagabaster, D. and J.M. Sierra. 2010. "Immersion and CLIL in English: More Differences than Similarities”. ELT Journal 64 (4): 367-375.

Leone, A. R. (2015). Outlooks in Italy: CLIL as Language Education Policy. Working Papers in Educational Linguistics 30 (1), http://repository.upenn.edu/wpel/vol30/iss1/3

Lewis, G., B. Jones and C. Baker. 2012a. "Translanguaging: Origins and Development from School to Street and Beyond”. Educational Research and Evaluation 18 (7): 641-654.

Lewis, G., B. Jones and C. Baker. 2012b. "Translanguaging: Developing its Conceptualisation and Contextualisation.” Educational Research and Evaluation 18 (7): 655-670.

Llinares, A. and R. Whittaker. 2007. "Talking and writing in a Foreign Language in a CLIL Context: A Linguistic Analysis of Secondary School Learners of Geography and History" in Models and Practice in CLIL edited by Lorenzo, F., S. Casal; V. Alba-Quiñones and P. Moore, 83-94. La Rioja: RESLA.

Li, W. 2011. "Moment Analysis and Translanguaging Space: Discursive Construction of Identities by Multilingual Chinese Youth in Britain”. Journal of Pragmatics 43: 1222-1235.

Lin, A.M.Y. 2015. "Conceptualising the Potential Role of L1 in CLIL". Language, Culture and Curriculum 28 (1): 74-89. 
Littlewood, W. and B. Yu. 2011. "First Language and Target Language in the Foreign Language Classroom”. Language Teaching 44 (1): 64-77.

Lo, Y.Y. and A.M.Y. Lin. 2015. "Designing Multilingual and Multimodal CLIL Frameworks for EFL Students". International Journal of Bilingual Education and Bilingualism 18 (3): 261-269.

Macaro, E. 2006. "Strategies for Language Learning and for Language Use: Revising the Theoretical Framework". Modern Language Journal 90 (3): 320-337.

Makalela, L. 2013. "Translanguaging in kasi-taal: Rethinking old Language Boundaries for New Language Planning”. Stellenbosch Papers in Linguistics Plus 42: 111-125.

Marsh, D., P. Mehisto, D. Wolff and M.J. Frigols Martin. 2011. European Framework for CLIL Teacher Education. Graz: European Centre for Modern Languages.

Marsh, D., and G. Langé, eds. 1999. Implementing Content and Language Integrated Learning: A Research-Driven Foundation Reader, TIE-CLIL, Jyväskylä: University of Jyväskylä.

Martin-Beltrán, M. 2014. ““What Do You Want to Say?” How Adolescents Use Translanguaging to Expand Learning Opportunities". International Multilingual Research Journal. (Advanced access). doi: 10.1080/19313152.2014.914372

Méndez-García, M.C., and V. Pavón. 2012. "Investigating the Coexistence of the Mother Tongue and the Foreign Language through Teacher Collaboration in CLIL contexts: Perceptions and Practice of the Teachers involved in the Plurilingual Programme in Andalusia". International Journal of Bilingual Education and Bilingualism 15 (5): 573-592.

Moore, P. and T. Nikula. 2016. "Translanguaging in CLIL". In Conceptualising Integration in CLIL and Multilingual Education, edited by Nikula et al., 211-234, Clevedon: Multilingual Matters.

Nikula, T. 2005. "English as an object and tool of study in classrooms: Interactional effects and pragmatic implications". Linguistics and Education 16 (1): 27-58.

Nikula, T. 2007 "Speaking English in Finnish content-based classrooms". World Englishes 26 (2): 206-223.

Nikula, T., and K. Mård-Miettinen. 2014. "Language learning in immersion and CLIL classrooms". In Handbook of Pragmatics 18, edited by J.-O. Östman, and J. Verschueren, 1-24, Amsterdam: John Benjamins.

Nikula, T., E. Dafouz, P. Moore and U. Smit. 2016. Conceptualising Integration in CLIL and Multilingual Education. Clevedon: Multilingual Matters. 
Orman, J. 2013. "New Lingualisms, Same Old Codes”. Language Sciences 37: 90-98.

Otsuji, E., and A. Pennycook. 2010. "Metrolingualism: Fixity, Fluidity and Language in Flux". International Journal of Multilingualism 7 (3): 240-254.

Schwartz, M., and A. Asli. 2014. 'Bilingual Teachers' Language Strategies: the Case of an Arabic-Hebrew Kindergarten in Israel”. Teaching and Teacher Education 38: 2232.

Somers, T., and J. Surmont. 2012. "CLIL and Immersion: How Clear Cut are they?" ELT Journal 66 (1): 113-116.

Storch, N., and G. Wigglesworth. 2003. "Is There a Role for the Use of the L1 in an L2 Setting?” TESOL Quarterly 37 (4): 760-770.

Torres, L. 2002. "Bilingual Discourse Markers in Puerto Rican Spanish”. Language in Society 31 (1): 65-83.

Turner, M. 2013. "CLIL in Australia: the Importance of Context". International Journal of Bilingual Education and Bilingualism 16 (4): 395-410.

Üstünel, E., and P. Seedhouse. 2005. "Why That, in That Language, Right Now? Codeswitching and Pedagogical Focus". International Journal of Applied Linguistics 15 (3): 302-324.

Williams, C. 1996. "Secondary education: Teaching in the Bilingual Situation". In The Language Policy: Taking Stock, edited by C. Williams, G. Lewis, and C. Baker, 3978. Llangefni, UK: CAI.

Williams, C. 2002. Extending Bilingualism in the Education System. Report presented to the Welsh Assembly. Retrieved from http://www.assemblywales.org/3c91c7af00023d820000595000000000.pdf 